\title{
ANTIFUNGAL ACTIVITY OF LEATHER TREATED WITH Anethum graveolens AND Melaleuca alternifolia ESSENTIAL OILS AGAINST Trichophyton interdigitale
}

\author{
Mariana Daniela BERECHET ${ }^{1 *}$, Corina CHIRILĂ ${ }^{1}$, Demetra SIMION ${ }^{1}$, Olga NICULESCU ${ }^{1}$, \\ Maria STANCA ${ }^{1}$, Cosmin-Andrei ALEXE ${ }^{1}$, Ciprian CHELARU ${ }^{1}$, Maria RÂPĂ², Dana Florentina GURĂU ${ }^{1}$ \\ ${ }^{1}$ INCDTP - Division: Leather and Footwear Research Institute (ICPI), Bucharest, 031215, Romania, marianadanielaberechet@ \\ yahoo.co.uk \\ ${ }^{2}$ Polytechnic University of Bucharest
}

Received: 18.10 .2019

Accepted: 25.05 .2020

https://doi.org/10.24264/Ifj.20.2.4

\section{ANTIFUNGAL ACTIVITY OF LEATHER TREATED WITH Anethum graveolens AND Melaleuca alternifolia ESSENTIAL OILS AGAINST} Trichophyton interdigitale

ABSTRACT. Trichophyton interdigitale is a common fungus causing onychomycosis of the nail in humans. Plants are a rich source of bioactive compounds with antifungal properties used in various compositions in pharmaceuticals, cosmetics or various industrial products. In the present paper, the antifungal activity of two kinds of leathers was tested: ecologically processed sheepskin leather lining (Eco) and sheepskin leather lining processed with basic chromium salts $(\mathrm{Cr})$, treated with Anethum graveolens and Melaleuca alternifolia essential oils. Dill (Anethum graveolens) essential oil rich in o-cymene (30.71\%) and $\alpha$-phellandrene (23.21\%) and tea tree (Melaleuca alternifolia) essential oil rich in terpinene-4-ol (23.06\%) were used. The results obtained in this study show that the essential oil of Anethum graveolens and Melaleuca alternifolia had a high antifungal effect against Trichophyton interdigitale. Tea tree and dill essential oils offer a much safer alternative protection against fungi as compared to synthetic compounds with adverse reactions to body and environment. The results of this study may have potential for use in developing applications for cosmetics, pharmaceuticals, obtaining leathers and textiles with selective bioproperties. KEY WORDS: Anethum graveolens and Melaleuca alternifolia essential oil, antifungal activity, Trichophyton interdigitale, sheepskin leather lining

\section{ACTIVITATEA ANTIFUNGICĂ A PIEILOR TRATATE CU ULEIURI ESENȚIALE DE Anethum graveolens ȘI Melaleuca alternifolia îMPOTRIVA} Trichophyton interdigitale

REZUMAT. Trichophyton interdigitale este un fung comun care provoacă onicomicoza unghiei la om. Plantele sunt o sursă bogată de compuși bioactivi cu proprietăți antifungice utilizate în diferite compoziții în produse farmaceutice, produse cosmetice sau diverse produse industriale. În lucrarea de față s-a testat activitatea antifungică pe două tipuri de piele: căptușeala din piele de oaie procesată ecologic (piele Eco) și căptușeala din piele de oaie procesată cu săruri bazice de crom (piele $\mathrm{Cr}$ ) tratate cu uleiuri esențiale de Anethum graveolens și Melaleuca alternifolia. S-a folosit ulei esențial de mărar (Anethum graveolens) bogat în o-cimol (30,71\%) și $\alpha$-felandren (23,21\%) și ulei esențial de arbore de ceai (Melaleuca alternifolia) bogat în terpinen-4-ol (23,06\%). Rezultatele obținute în acest studiu arată că uleiurile esențiale de Anethum graveolens și Melaleuca alternifolia au avut un efect antifungic ridicat împotriva Trichophyton interdigitale. Uleiurile esențiale de arbore de ceai și mărar oferă o alternativă de protectie mult mai sigură împotriva ciupercilor, comparativ cu compușii sintetici, care prezintă reacții adverse pentru corp și mediu. Rezultatele acestui studiu pot avea potențial de utilizare în dezvoltarea aplicațiilor în produse cosmetice, farmaceutice, obținerea de piei și textile cu bioproprietăți selective.

CUVINTE CHEIE: ulei esențial de Anethum graveolens și Melaleuca alternifolia, activitate antifungică, Trichophyton interdigitale, piei ovine pentru căptușeli

\section{L'ACTIVITÉ ANTIFONGIQUE DES CUIRS TRAITÉS AVEC DES HUILES ESSENTIELLES D’Anethum graveolens ET Melaleuca alternifolia CONTRE Trichophyton interdigitale}

RÉSUMÉ. Trichophyton interdigitale est un champignon commun provoquant l'onychomycose des ongles chez l'homme. Les plantes sont une riche source de composés bioactifs aux propriétés antifongiques utilisés dans diverses compositions pharmaceutiques, cosmétiques ou divers produits industriels. Dans cet article, on a testé l'activité antifongique de deux types de cuirs : la doublure en cuir de mouton traitée écologiquement (Eco) et la doublure en cuir de mouton traitée avec des sels basiques de chrome (Cr), traités avec des huiles essentielles d'Anethum graveolens et Melaleuca alternifolia. L'huile essentielle d'aneth (Anethum graveolens) riche en o-cymène (30,71\%) et $\alpha$-phellandrène $(23,21 \%)$ et l'huile essentielle d'arbre à thé (Melaleuca alternifolia) riche en terpinène-4-ol (23,06\%) ont été utilisées. Les résultats obtenus dans cette étude montrent que l'huile essentielle d'Anethum graveolens et Melaleuca alternifolia ont eu un effet antifongique élevé contre Trichophyton interdigitale. Les huiles essentielles d'arbre à thé et d'aneth offrent une protection alternative beaucoup plus sûre contre les champignons par rapport aux composés synthétiques ayant des réactions indésirables au corps et à l'environnement. Les résultats de cette étude peuvent avoir un potentiel d'utilisation dans le développement d'applications dans les cosmétiques, les produits pharmaceutiques, l'obtention de cuirs et de textiles à propriétés biologiques sélectives.

MOTS CLÉS : huile essentielle d'Anethum graveolens et Melaleuca alternifolia, activité antifongique, Trichophyton interdigitale, peau de mouton pour doublures

\footnotetext{
* Correspondence to: Mariana Daniela BERECHET, INCDTP - Division: Leather and Footwear Research Institute (ICPI), Bucharest, 031215, Romania, marianadanielaberechet@yahoo.co.uk
} 


\section{INTRODUCTION}

Plants are a rich source of bioactive compounds with antifungal properties used in various compositions in pharmaceuticals, cosmetics or various industrial products [1]. Medicinal plants have been used to treat various affections for thousands of years, because they are vast and diverse compositions of natural compounds that can have important selective bioproperties. The most important of these compounds are alkaloids, tannins, flavonoids, terpenoids, saponins and phenolic compounds. Researchers, pharmacists, doctors are interested in these compounds due to their bioactivity and low toxicity [2]. Many compounds were isolated from plants that could be used for the development of new compositions to inhibit growth of fungal pathogens with possibly new mechanisms of action [3]. Extensive studies have already been reported for the use of essential oils from plants as biocides in leather processing [4-9] and in the protection of footwear against the growth of microorganisms which are mainly responsible for the appearance of fungal infections on the nails [4, 10-13]. Considering the side effects of antifungal drugs obtained by chemical synthesis, remedies based on natural compounds are a safe choice for treating fungal infections. They have no side effects as have other medicines. Essential oils are a natural remedy to prevent and treat fungal infections. If used in optimal proportions, essential oils with antifungal properties are a natural way to cure fungal diseases of the foot such as athlete's foot, or treat other demanding areas of the foot [4]. The use of essential oils in biological control against fungi is mainly due to their richness in antifungal substances [14-18]. Numerous studies have established the efficacy of Anethum graveolens essential oil from the Apiaceae family [1] and Melaleuca alternifolia essential oil from the Myrtaceae family [19] against fungi [20-22]. Many members from these families are economically useful for medicines, cosmetics and various commercial uses [23]. Previous studies on the essential oils of Apiaceae and Myrtaceae have shown that these plants have a wide range of biological activities, in particular antifungal and antimicrobial potential. The chemical nature of the main ingredients was directly related to this activity [24]. Several previous studies have focused on chemical composition and antifungal effect of Anethum graveolens and Melaleuca alternifolia essential oils. Thus, their rich content in monoterpenes, gives an antifungal, antioxidant and antimicrobial activity. These properties promise their use as a natural antifungal in various pharmaceutical, cosmetic, industrial applications $[25,26]$. There is much interest to find antimicrobial and antifungal agents to treat the shoe lining leather. For example, Koizhaiganova et al. studied the leather treated with silver doped hydroxyapatite. Good antibacterial properties against $S$. aureus, B. subtilis, E. faecalis as Gram positive bacteria, E. coli, S. typhimurium, K. pneumoniae and $P$. aeruginosa as Gram negative bacteria and the yeast $C$. albicans were reported with the increasing concentration of Ag [27]. In our previous paper, we presented the antifungal and antibacterial effects of geranium, pine, and rosemary essential oils on the cotton and leather linings with good results [28]. This fungus causes onychomycosis (also known as tinea unguium, a fungal infection on the nail) and tinea pedis (skin infection on the feet causes by fungus) in humans [30-32].

The aim of this paper is to test the antifungal effect of the essential oil extracted from dill (Anethum graveolens) and tea tree (Melaleuca alternifolia) against Trichophyton interdigitale on sheepskin lining leather used in the production of footwear, to avoid the appearance of nail fungus or bad smell of shoes by using natural antifungal agents.

\section{EXPERIMENTAL}

\section{Materials and Methods}

\section{Materials}

Anethum graveolens essential oil (EO) was acquired from S.C. Herbavit S.R.L. Oradea, Romania. Melaleuca alternifolia essential oil (EO) was acquired from S.C. Solaris Plant Radix S.R.L. Bucharest, Romania and Borron SE from Triderma SRL Bucharest. Sheepskin leather lining was processed at the National Research and Development Institute for Textiles and Leather - Division: Leather and Footwear Research Institute (INCDTP-ICPI), Bucharest. 
Methods

\section{Sheepskin Lining Leather}

Sheepskin lining leather obtained by ecological processing without basic chromium salts (lining leather Eco) and sheepskin lining leather obtained by processing with basic chromium salts (lining leather $\mathrm{Cr}$ ) were used. The samples of sheepskin lining leather were treated by immersion in $200 \%$ aqueous float with $5 \%$ essential oil and $5 \%$ Borron SE, relative to the weight of the lining materials, at $25^{\circ} \mathrm{C}$ for 30 minutes with stirring and then free dried at $25^{\circ} \mathrm{C}$.

\section{GC-MS Analysis}

Chemical composition of essential oils was determined by Gas chromatography-Mass Spectrometry (GC-MS) with Agilent 6890 N and the majority constituent compounds were identified [29].

\section{ATR-FTIR Analysis}

The chemical structures of investigated leather samples were analyzed by use of Fourier Transform Infrared Spectroscopy-Attenuated Total
Reflectance FT-IR/ATR spectrometer JASCO FT-IR 4200. The spectra were accumulated from 16 scans in a range of $4000-400 \mathrm{~cm}^{-1}$ scale, with a scan speed of $2.2 \mathrm{KHz}$ and a resolution of $4 \mathrm{~cm}^{-1}$, single-beam, with ATR accessory with diamond sensor.

\section{Antifungal Activity Assessment}

The antifungal activity was evaluated using Trichophyton interdigitale fungus. Figure 1 shows the culture of 7-day-old Trichophyton interdigitale grown on Sabouraud dextrose agar culture medium and analyzed using an optical microscope. The tests were performed in accordance with ASTM D4576-86:2016 - Standard Test Method for Mold Growth Resistance of Wet Blue and Wet White. In each Petri dish a Dextrose Agar Sabouraud culture medium was poured. Treated samples and control samples were placed in Petri dishes in the center of the surface of the culture medium, and then the culture medium was seeded in 3 points around the sample with Trichophyton interdigitale fungus, as an equilateral triangle. Petri dishes were placed in thermo-hygrostat (Memmert) at the temperature of $30^{\circ} \mathrm{C}$ and were analyzed after 3, 7, 14 and 21 days.
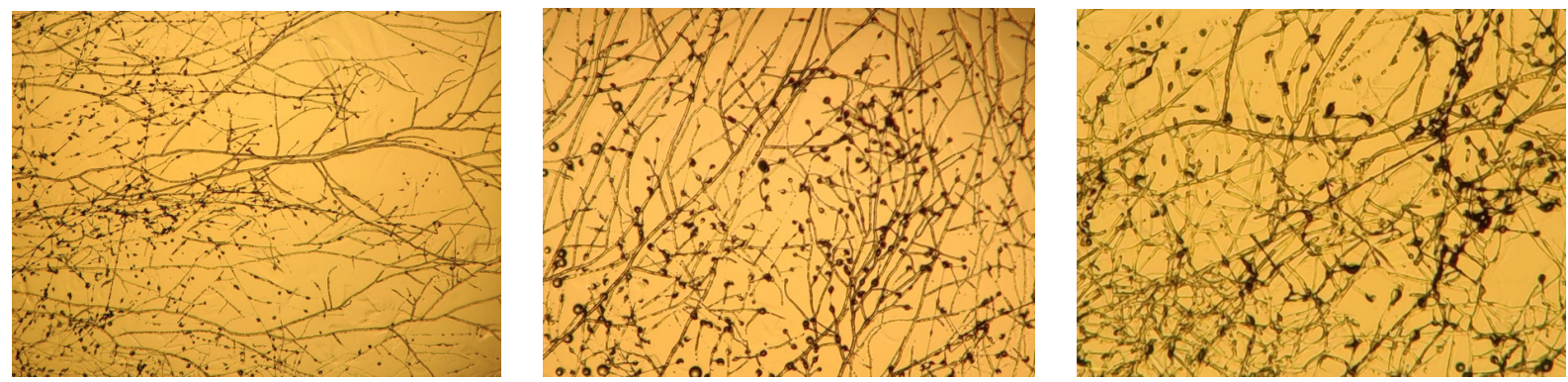

Figure 1. Trichophyton interdigitale fungus, optical microscopy images, 40x

\section{Optical Microscopy Investigation}

Optical microscopy images were captured using a Leica stereomicroscope S8APO model with optical fiber cold light source, L2, with three levels of intensity, and 40X magnification.

\section{RESULTS AND DISCUSSIONS}

\section{GC-MS Analysis of Essential Oils}

The major compounds identified in Anethum graveolens essential oil were o-cymene with an area percentage of $30.71 \%$, and $\alpha$-phellandrene with an area percentage of 23.21\%; other compounds had lower area percentages $[1,29]$. The GC-MS analysis in the case of Melaleuca alternifolia essential oil showed that the major compound was terpinene-4-ol with an area percentage of 23.06\% [14] (Figure 2). The chemical composition of tea tree essential oil consists largely of cyclic monoterpenes of which about $50 \%$ are oxygenated and about $50 \%$ are hydrocarbons [20]. 


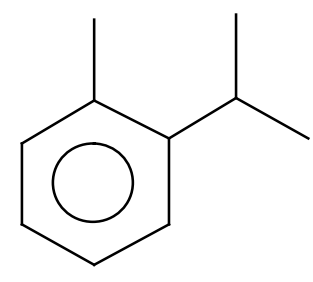

o-cimole<smiles>CC1=CCC(C(C)C)CC1</smiles>

$\alpha$-felandren<smiles>CC1=CCC(O)(C(C)C)CC1</smiles>

terpinene-4-ol

Figure 2. The main components of dill and tea tree essential oils

\section{ATR-FTIR Analysis of Leathers}

Mid-infrared spectra for un-treated leather lining - Eco control and leather lining $\mathrm{Cr}$ control and leather samples treated with dill or tea tree essential oil are shown in Figures 3, 4 and 5. According to FTIR spectra from Figure 3 , the characteristic bands of sheepskin leather lining - Eco control (a) and sheepskin leather lining - $\mathrm{Cr}$ control (b) are observed. Vibration bands at $1449 \mathrm{~cm}^{-1}, 2853 \mathrm{~cm}^{-1}$ and $3086 \mathrm{~cm}^{-1}$ are attributed to hydrogen bonds of associated functional groups $\mathrm{C}-\mathrm{H}$ and those at $1082 \mathrm{~cm}^{-1}$ and $3318 \mathrm{~cm}^{-1}$ are attributed to hydrogen bonds of associated functional groups C-O [27]. Bands in the range of $3318-3307 \mathrm{~cm}^{-1}$ are related to $\mathrm{O}-\mathrm{H}$ stretching. Peaks in the ranges of $1636-$ $1633 \mathrm{~cm}^{-1}$ (-C=C stretch), $1548-1547 \mathrm{~cm}^{-1}$ and at $1236 \mathrm{~cm}^{-1}$ are attributed to I, II and III amide bands, respectively. Peaks of the $\mathrm{C}-\mathrm{O}$ band were observed at $1032 \mathrm{~cm}^{-1}$ in the case of sheepskin leather lining - Eco control, $1085-1082 \mathrm{~cm}^{-1}$ and $1166-1655 \mathrm{~cm}^{-1}$ in all samples.

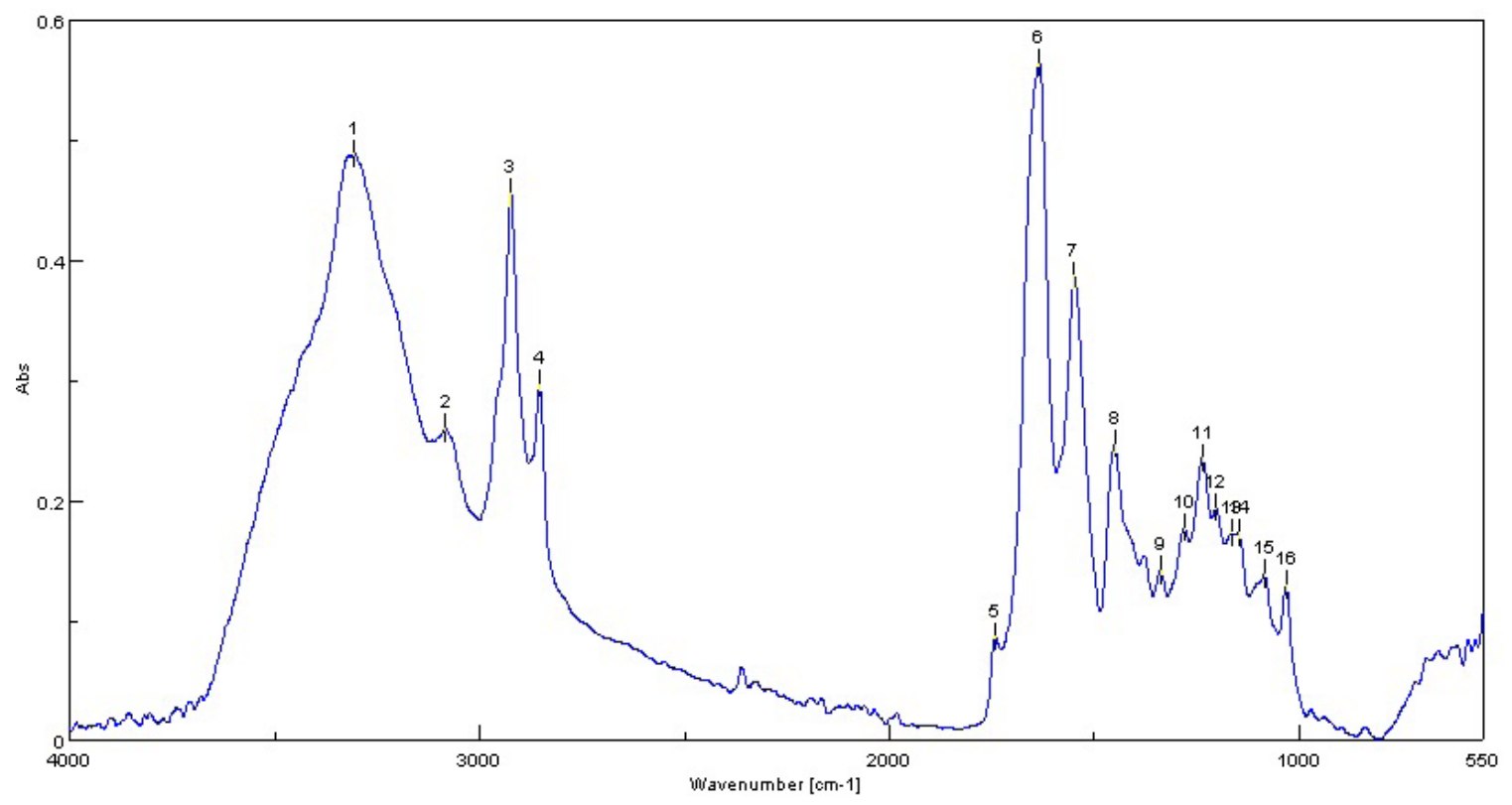

(a) 


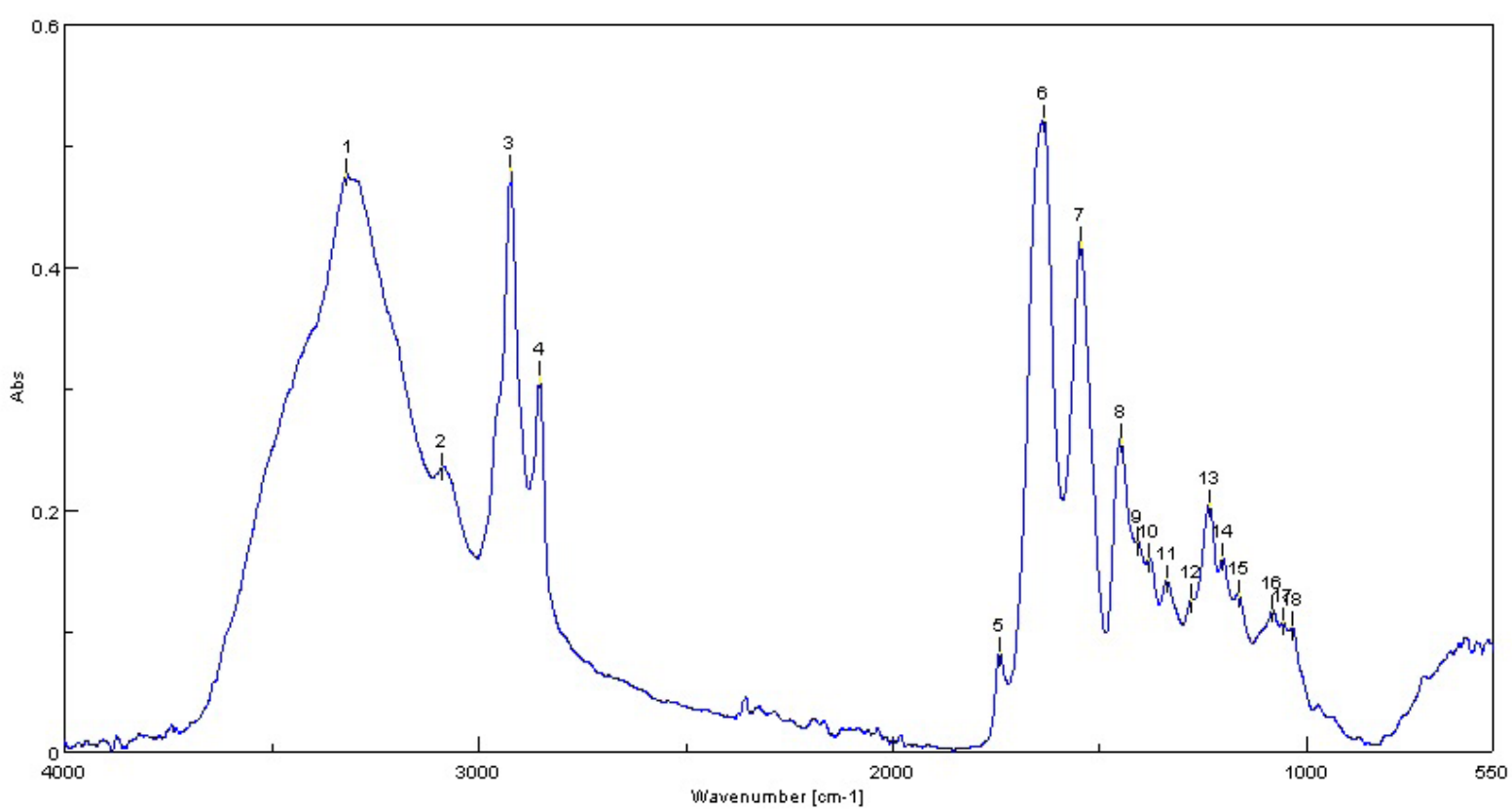

(b)

Figure 3. ATR-FTIR spectra for (a) sheepskin leather lining - Eco control, and (b) sheepskin leather lining - Cr control

The chemical changes occurring in the functional groups in the leather lining treated with tea tree essential oils are shown in Figure 4 compared to spectra for tea tree essential oil.

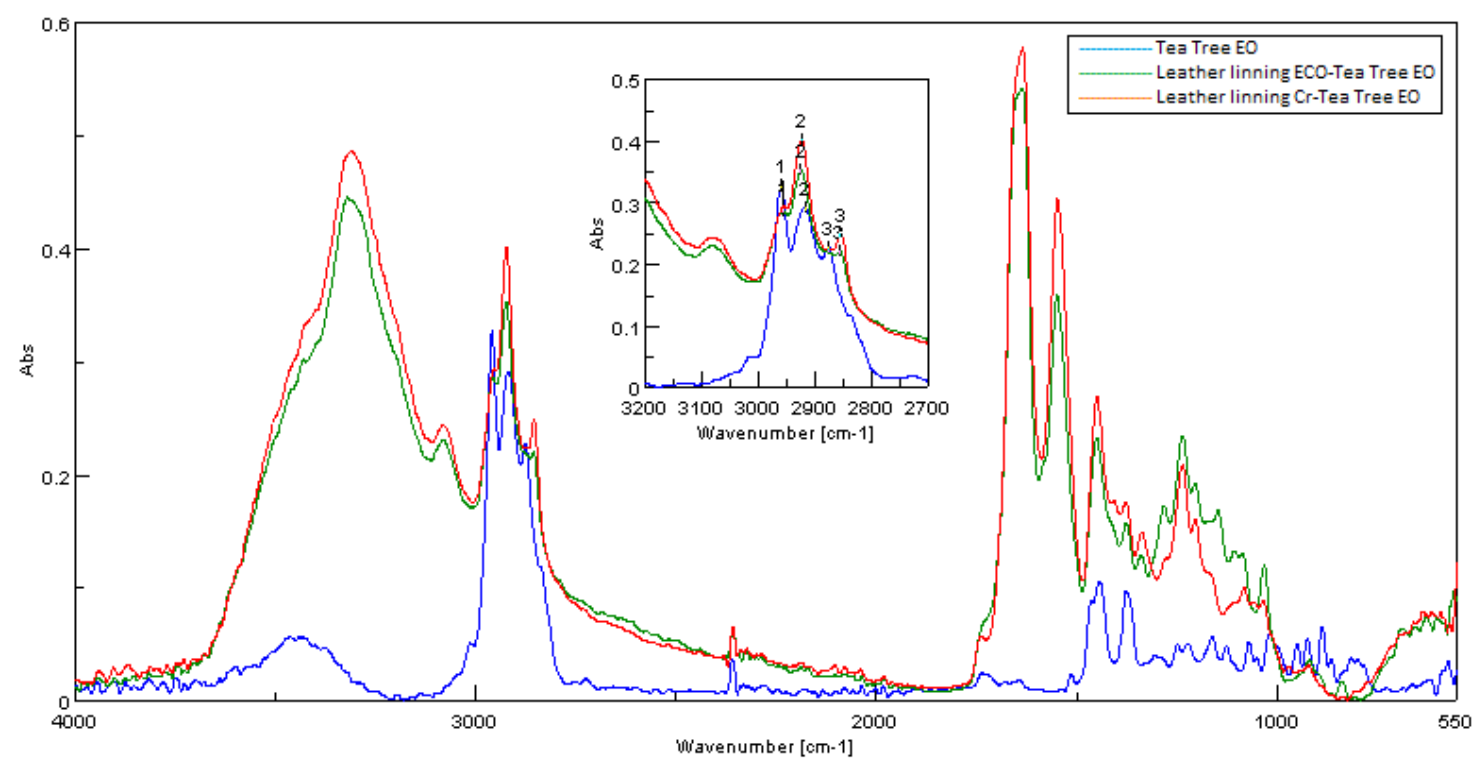

Figure 4. ATR-FTIR spectra of tea tree EO, leather lining - Eco and leather lining - Cr treated with tea tree EO

The treatment of sheepskin lining - Eco and sheepskin lining - $\mathrm{Cr}$, respectively with tea tree essential oil leads to the evidence of absorption bands at 2958-2956 $\mathrm{cm}^{-1}$ (C-H stretch), 1449$1448 \mathrm{~cm}^{-1}$ (C-H bending) specific for this EO
[33]. The absorption band at $2919 \mathrm{~cm}^{-1}\left(-\mathrm{CH}_{2}\right.$ - as well as from the asymmetric $-\mathrm{CH}\left(\mathrm{CH}_{3}\right)$ stretching vibration [34]) is shifted to $2925-2924 \mathrm{~cm}^{-1}$ in the case of treated leather lining samples. The band at $2877 \mathrm{~cm}^{-1}\left(-\mathrm{CH}\left(\mathrm{CH}_{2}\right)-\right.$, symmetric and 
asymmetric stretching vibrations) identified at tea tree spectrum [34] is found in the range of $2856-2855 \mathrm{~cm}^{-1}$ in the spectra of leather samples treated with tea tree EO. The bands at 3318-3307 $\mathrm{cm}^{-1}, 1548-1547 \mathrm{~cm}^{-1}$ found in control samples are also observed at the treated samples with tea tree essential oil. The band at $1441 \mathrm{~cm}^{-1}$ observed in the case of tea tree EO due the $-\mathrm{CH}_{2}-$ and $-\mathrm{CH}_{3}$ scissoring vibration [34] is shifted in the range of $1449-1449 \mathrm{~cm}^{-1}$ for treated leather samples.

Figure 5 shows comparative spectra for dill EO, leather lining - Eco and leather lining - $\mathrm{Cr}$ treated with dill essential oil.

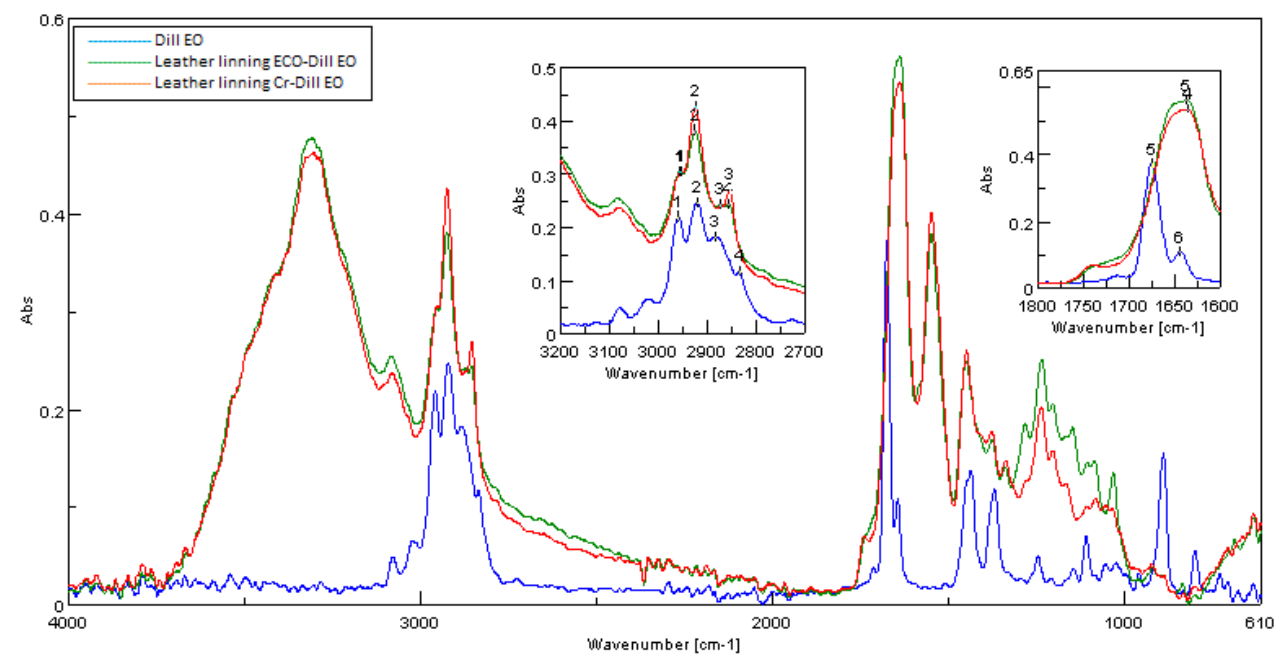

Figure 5. ATR-FTIR spectra of dill EO, leather lining - Eco treated with dill EO and leather lining - $\mathrm{Cr}$ treated with dill EO

The FTIR analysis of treated lining leather samples with dill essential oil is accompanied by the shifting of wave number from $2953 \mathrm{~cm}^{-1}$ and 2922 $\mathrm{cm}^{-1}$ (C-H stretch) assigned to EO to 2957-2955 $\mathrm{cm}^{-1}$ and $2925-2924 \mathrm{~cm}^{-1}$. The characteristic band of EO from $2884 \mathrm{~cm}^{-1}$ assigned to $\mathrm{CH} 3$ stretching is moved to lower wave number $\left(2874 \mathrm{~cm}^{-1}\right)$ in the case of treated sheepskin lining Eco leather.

The bands at $3318 \mathrm{~cm}^{-1}$ and $3307 \mathrm{~cm}^{-1}(\mathrm{O}-\mathrm{H}$ stretching) from sheepskin lining - $\mathrm{Cr}$ spectrum and sheepskin lining - Eco spectrum are found in the treated samples with dill EO. The bands at $1644 \mathrm{~cm}^{-1}$ (-C=C stretch) and $1675 \mathrm{~cm}^{-1}(\alpha-\beta$ unsaturated $C=O$ stretch) [33] from dill EO are shifted to $1637-1637 \mathrm{~cm}^{-1}$ for treated samples.

The spectra presented in Figures 4-5 confirm the presence of tea tree or dill essential oils in the sheepskin lining samples.

\section{Antifungal Activity against Trichophyton interdigitale}

Samples of sheepskin leather lining - Eco control and treated with tea tree and dill essential oil was incubating at $30^{\circ} \mathrm{C}$ and the antifungal activity towards the grown of
Trichophyton interdigitale was evaluated after $3,7,14$, and 21 days (Table 1). Antifungal activity against Trichophyton interdigitale was ranked with indicators between $0-5$, where 0 means that no microorganisms grew on the sample surface, 1 shows growth between 10$20 \%$, 2 between $30-45 \%, 3$ between $50-75 \%$, 4 between $80-90 \%$ and 5 shows $100 \%$ growth of microorganisms on the evaluated sample surface. Control sheepskin leather lining - Eco samples show growth of microorganisms after 3 days on $90 \%$ of leather surface and it increases at $100 \%$ after 7 days. Sheepskin leather lining - Eco samples treated with tea tree essential oil show no growth of microorganisms after 3 days, 7 days and 14 days respectively, remaining without growth of Trichophyton interdigitale fungus on leather surface and on culture environment. After 21 days their growth covers $80 \%$ of the leather sample surface. Sheepskin leather lining - Eco samples treated with dill essential oil show no growth of microorganisms after 3 days and 7 days, respectively. After 14 days the microorganism growth was $10 \%$ on the surface of leather and it did not evolve after 21 days. 
Table 1: Sheepskin lining leathers - Eco treated with tea tree and dill essential oil tested against Trichophyton interdigitale fungus as compared with control samples

Sample
$\begin{gathered}\text { Control } \\ \text { sheepskin } \\ \text { leather lining } \\ \text { - Eco }\end{gathered}$

Also, samples of sheepskin leather lining - $\mathrm{Cr}$ control and treated with tea tree and dill essential oil, respectively, were incubated at $30^{\circ} \mathrm{C}$ for $3,7,14$, and 21 days, respectively. After each test period, the antifungal activity was evaluated against Trichophyton interdigitale (Table 2). Control sheepskin leather lining - Eco samples show growth of microorganisms after 3 days on $20 \%$ from leather surface and increases at $100 \%$ after 7 days. Sheepskin leather lining - $\mathrm{Cr}$ samples treated with tea tree essential oil show no growth of microorganisms on the leather surface after 21 days of exposure. Sheepskin leather lining - $\mathrm{Cr}$ samples treated with dill essential oil show no growth of microorganisms after 3 days and 7 days, respectively. After 14 days, the microorganism growth was $100 \%$ on the surface of leather.

Table 2: Sheepskin lining leathers - $\mathrm{Cr}$ treated with tea tree and dill essential oil tested against Trichophyton interdigitale fungus as compared with control samples

Sample
$\begin{gathered}\text { Control } \\ \text { sheepskin } \\ \text { leather lining } \\ -\mathrm{Cr}\end{gathered}$


In the case of treatment of leather - Eco samples with tea tree EO, a good resistance against Trichophyton interdigitale microorganism with zero growth after 14 days, and no microorganism growth on leather with $\mathrm{Cr}$ sample were recorded throughout the experiment. Tea tree essential oil compounds affected cell membranes in microorganisms and induced cell membrane rupture [23]. Tea tree oil has a broad spectrum of antifungal and antimicrobial activity [35] which can be mainly attributed to the major compound, terpinen-4ol [36,37], through an action of penetrating the cell wall and cell membrane structures that stops the development of microorganisms [25].

Leather samples treated with dill essential oil has improved/better antifungal activity in the case of sheepskin leather lining Eco with zero growth of microorganism up to 7 days and an increase up to $10 \%$ surface coverage after 14 days. Sheepskin leather lining - $\mathrm{Cr}$ has also no growth of Trichophyton interdigitale up to 7 days and shows $100 \%$ increase after 14 days. In another study, it was reported that the dill seed essential oil $(1.00 \mu \mathrm{L} / \mathrm{mL})$ completely inhibited the growth of $S$. sclerotiorum fungus after 4 days of incubation due to the carvone and limonene content [22]. A completely inhibition of the growth of Trichophyton interdigitale species during 28 days on the sheepskin leather for lining finished with synthetic film was observed in the case of treatment with thyme essential oil [4]. The mechanism of the dill essential oil on the fungal inhibition could be explained by the low molecular weight and highly lipophilic compounds (terpene) that disrupt the fungus membrane [38]. In the case of tea tree essential oil, the fungal activity was assigned to the terpene-4-ol that exhibits antimycotic activities by disrupting cell walls, membranes and cytoplasm, which led to compromising fungal life processes [39].

A wide variety of essential oils have antifungal and antimicrobial properties and in many cases this activity is due to the presence of active monoterpenic constituents [4042]. Several studies have also shown that monoterpenes exert a membrane dam with effects of cell aging and stopping the development of microorganisms [25, 43]. Essential oils used in optimal proportions have selective bioactive properties and no side effects [44]. The antifungal activity of tea tree and dill essential oils against Trichophyton interdigitale makes it possible to develop antifungal compositions based on natural compounds for footwear, gloves and other specific products [44].

\section{CONCLUSIONS}

The results obtained in this study show that the essential oils of Anethum graveolens and Melaleuca alternifolia had different antifungal effects against Trichophyton interdigitale depending on the tested period and type of leather tanning. The experiments showed that the tea tree essential oil totally inhibited the growth of Trichophyton interdigitale fungus on the sheepskin leather lining - $\mathrm{Cr}$ up to 21 days of exposure and on the sheepskin leather lining - Eco up to 14 days of exposure. The dill essential oil shown to enhance the growth inhibition of the Trichophyton interdigitale fungus up to 7 days. The results are promising for treatment of lining leather with essential oils having a great importance for foot health and hygiene. Also, tea tree and dill essential oils could offer a much safer alternative protection against fungus as compared to synthetic compounds with adverse reactions to body and environment. The results of this study may have potential for use in application development in cosmetics, pharmaceuticals, obtaining leathers and textiles with selective bioproperties. 
Acknowledgements

The research was carried out under project number 19 Nucleu / 2019, PN 191701 02, CREATIV_PIEL, 6PFE_4PERFORM-TEX-PEL/2018 project, and funded by Romanian Ministry of Education and Research.

\section{REFERENCES}

1. Akhtar, N., Ihsan-ul-Haq, Mirza, B., Phytochemical analysis and comprehensive evaluation of antimicrobial and antioxidant properties of 61 medicinal plant species, Arab J Chem, 2018, 11, 1223-1235, https:// doi.org/10.1016/j.arabjc.2015.01.013.

2. Inayatullah, S., Prenzler, P.D., Obied, H.K., Rehman, A.U., Mirza, B., Bioprospecting traditional Pakistani medicinal plants for potent antioxidants, Food Chem, 2012, 132, 222-229, https://doi.org/10.1016/j. foodchem.2011.10.060.

3. Ahmad, I., Aqil, F., In vitro efficacy of bioactive extracts of 15 medicinal plants against ESBL-producing multidrug-resistant enteric bacteria, Microbiol Res, 2007, 162, 264-275, https://doi.org/10.1016/j. micres.2006.06.010.

4. Chirilă, C., Deselnicu, V., Berechet, M.D., Footwear protection against fungi using thyme essential oil, Leather and Footwear Journal, 2017, 17, 3, https://doi.org/10.24264/ Ifj.17.3.7.

5. Berechet, M.D., Chirila, C., Deselnicu, V., Antifungal Activity of Thyme Essential Oil on Woolen Sheepskins, Proceedings of the $6^{\text {th }}$ International Conference on Advanced Materials and Systems - ICAMS 2016, 20-23 October 2016, Bucharest, Romania, 203-208, https://doi.org/10.24264/icams-2016.II.2.

6. Chirila, C., Berechet, M.D., Deselnicu, V., Thyme Essential Oil as Natural Leather Preservative against Fungi, Proceedings of the $6^{\text {th }}$ International Conference on Advanced Materials and Systems - ICAMS 2016, 20-23
October 2016, Bucharest, Romania, 227-232, https://doi.org/10.24264/icams-2016.II.6.

7. Chirila, C., Crudu, M., Deselnicu, V., Comparative Study regarding Resistance of Wet-White and Wet-Blue Leather to the Growth of Fungi, Leather and Footwear Journal, 2014, 14, 2, 107-120, https://doi.org/10.24264/Ifj.14.2.4.

8. Chirila, C., Crudu, M., Deselnicu, V., Study regarding the Resistance to the Growth of Fungi of Wet-White Leather Tanned with Titanium - Aluminum, Proceedings of the $5^{\text {th }}$ International Conference on Advanced Materials and Systems - ICAMS 2014, 23-25 October 2014, Bucharest, Romania, 31-36, ISSN: 2068-0783, CERTEX press.

9. Chirila, C., Deselnicu, V., Crudu, M., Study regarding the Resistance of Wet-White Leather Organic Tanned to the Growth of Fungi, Proceedings of the $5^{\text {th }}$ International Conference on Advanced Materials and Systems - ICAMS 2014, 23-25 October 2014, Bucharest, Romania, 37-42, ISSN: 2068-0783, CERTEX press.

10. Deselnicu, D.C., Vasilescu, A.M., Purcarea, A.A., Militaru, G., Sustainable Consumption and Production in the Footwear Sector, Leather and Footwear Journal, 2014, 14, 3, 159-180, https://doi.org/10.24264/Ifj.14.3.3.

11. Deselnicu, V., Deselnicu, D.C., Vasilescu, A.M., Militaru, G., EU Policy for Sustainable Consumption and Production - EU Ecolabel for Footwear, Proceedings of the $5^{\text {th }}$ International Conference on Advanced Materials and Systems - ICAMS 2014, 23-25 October 2014, Bucharest, Romania, 641-646, ISSN: 2068-0783, CERTEX press.

12. Deselnicu, V., Maier, S.S., Albu, L., Buruntea, N., Antimicrobial and Antifungal Leathers for Increasing the Health and the Comfort of the Individuals, CORTEP 2007, 18-21 October 2007, Iasi, Romania.

13. Deselnicu, V., Maier, S.S., Deselnicu, O.C., Florescu, M., Impact of Technological Changes on Increased Health and Comfort Efficiency, Proceedings of the $4^{\text {th }}$ International Conference in Management of Technological 
Change, Book 1, Chania, Greece, 19-20 August 2005, 87-92.

14. Chidi, F., Bouhoudan, A., Khaddor, M., Antifungal effect of the tea tree essential oil (Melaleuca alternifolia) against Penicillium griseofulvum and Penicillium verrucosum, J King Saud Univ Sci, 2020, 2041-2045, https:// doi.org/10.1016/j.jksus.2020.02.012.

15. Foganholi, A.P. do A.M., Daniel, J.F.S., Santiago, D.C., Orives, J.R., Pereira, J.P., Faria, T. de J., Chemical composition and antifungal activity of pennyroyal essential oil in different stages of development, Semina Ciênc Agrár, Londrina, 2015, 36, 3091-3100, https://doi. org/10.5433/1679-0359.2015v36n5p3091.

16. Hmiri, S., Rahouti, M., Habib, Z., Satrani, B., Ghanmi, M., El Ajjouri, M., Évaluation du potential antifongique des huiles essentielles de Mentha pulegium et d'Eucalyptus camaldulensis dans la lute biologique contre les champignons responsables de la détérioration des pommes en conservation, Bull Soc $R$ Sci Liège, 2011, 80, 824-836, available at https://popups.uliege. be:443/0037-9565/index.php?id=3375.

17. Khaddor, M., Saidi, R., Aidoun, A., Lamarti, A., Tantaoui-Elaraki, A., Ezziyyani, M., Castillo, M.C., Badoc, A., Antibacterial effects and toxigenesis of Penicillium aurantiogriseum and P. viridicatum, Afr J Biotechnol, 2007, 6, 2314-2318, https://doi.org/10.5897/ AJB2007.000-2362.

18. Louhibi, S., Amiri, S., Elghadraoui, L., Chemical composition and antimicrobial activity of essential oils, Thymus vulgaris L. and Mentha L. pulegium against the major post harvest diseases of citrus in Morocco, Int J Sci Res, 2015, 4, 1181-1184.

19. Cheng, S., Xingfeng, S., In vivo antifungal activities of the tea tree oil vapor against Botrytis cinereal, in: 2011 International Conference on New Technology of Agricultural, Presented at the 2011 International Conference on New Technology of Agricultural Engineering (ICAE), IEEE, Zibo, China, 2011, pp. 949-951.

20. Brophy, J.J., Davies, N.W., Southwell, I.A., Stiff, I.A., Williams, L.R., Gas chromatographic quality control for oil of melaleuca terpinen4-ol type (Australian Tea Tree), J Agric Food Chem, 1989, 37, 1330-1335, https://doi. org/10.1021/jf00089a027.

21. Ebani, V.V., Najar, B., Bertelloni, F., Pistelli, L., Mancianti, F., Nardoni, S., Chemical composition and in vitro antimicrobial efficacy of sixteen essential oils against Escherichia coli and Aspergillus fumigatus isolated from poultry, Vet Sci, 2018, 5, 62-74, https://doi. org/10.3390/vetsci5030062.

22. Ma, B., Ban, X., Huang, B., He, J., Tian, J., Zeng, $H_{\text {., }}$ et al., Interference and Mechanism of Dill Seed Essential Oil and Contribution of Carvone and Limonene in Preventing Sclerotinia Rot of Rapeseed, PLOS ONE, 2015, 10(7), e0131733, https://doi.org/10.1371/ journal.pone.0131733.

23. Lang, G., Buchbauer, G., A review on recent research results (2008-2010) on essential oils as antimicrobials and antifungals. A review, Flavour Fragr J, 2012, 27, 13-39, https://doi. org/10.1002/ffj.2082.

24. Nuzhat, T., Vidyasagar, G.M., Antifungal investigations on plant essential oils. A review, Int J Pharm Pharm Sci, 2013, 5, 19-28.

25. Cox, S.D., Mann, C.M., Markham, J.L., Bell, H.C., Gustafson, J.E., Warmington, J.R., Wyllie, S.G., The mode of antimicrobial action of the essential oil of Melaleuca alternifolia (tea tree oil), J Appl Microbiol, 2001, 88, 170-175, https://doi.org/10.1046/j.13652672.2000.00943.x.

26. Zhang, X., Guo, Y., Guo, L., Jiang, H., Ji, Q., In vitro evaluation of antioxidant and antimicrobial activities of Melaleuca alternifolia essential oil, BioMed Res Int, 2018, 8, https://doi.org/10.1155/2018/2396109.

27. Koizhaiganova, M., Yaşa, I., Gülümser, G., Assessment of antibacterial activity 
of lining leather treated with silver doped hydroxyapatite, Int Biodeterior Biodegradation, 2015, 105, 262-267, https:// doi.org/10.1016/j.ibiod.2015.09.017.

28. Berechet, M.D., Constantinescu, R.R., Râpă, M., Chirilă, C., Stanca, M., Simion, D., Surdu, L., Gurău, D.F., Antifungal and antibacterial treatments based on natural compounds for lining leather and footwear articles, Leather and Footwear Journal, 2019, 19, 4, 201-216, https://doi.org/10.24264/Ifj.19.4.5.

29. Berechet, M.D., Essential Oils - Their Use in Practice and Research, Doctoral Thesis, Faculty of Applied Chemistry and Materials Science, "Politehnica" University of Bucharest, 2015.

30. de Hoog, G.S., Dukik, K., Monod, M., Packeu, A., Stubbe, D., Hendrickx, M., Kupsch, C., Stielow, B., Freeke, J., Göker, M., RezaeiMatehkolaei, A., Mirhendi, H., Gräser, Y., Toward a Novel Multilocus Phylogenetic Taxonomy for the Dermatophytes, Mycopathologia, 2017, 182, 5-31, https:// doi.org/10.1007/s11046-016-0073-9.

31. Rodgers, P., Bassler, M., Treating onychomycosis, Am Fam Physician, 2001, 63, 4, 663-72, 677-8, PMID 11237081.

32. Westerberg, D.P., Voyack, M.J., Onychomycosis: current trends in diagnosis and treatment, Am Fam Physician, 2013, 88, 11, 762-70, PMID 24364524.

33. Kaur, N., Chahal, K.K., Kumar, A., Singh, R., Bhardwaj, U., Antioxidant activity of Anethum graveolens L. essential oil constituents and their chemical analogues, J Food Biochem, 2019, e12782, https://doi.org/10.1111/ jfbc.12782.

34. Gallart-Mateu, D., Largo-Arango, C.D., Larkman, T., Garrigues, S., de la Guardia, M., Fast authentication of tea tree oil through spectroscopy, Talanta, 2018, 189, 404-410, https://doi.org/10.1016/j. talanta.2018.07.023.

35. Markham, J.L., Biological activity of tea tree oil, in: Tea Tree, the Genus Melaleuca, ed. Southwell, I. and Lowe, R., Amsterdam: Harwood Academic Publishers, 1999, 169-190.

36. Southwell, I.A., Hayes, A.J., Markham, J.L., Leach, D.N., The search for optimally bioactive Australian tea tree oil, Acta Hortic, 1993, 334, 265-275, https://doi.org/10.17660/ ActaHortic.1993.344.30.

37. Carson, C.F., Riley, T.V., Antimicrobial activity of the major components of the essential oil of Melaleuca alternifolia, J Appl Bacteriol, 1995, 78, 264-269, https://doi. org/10.1111/j.1365-2672.1995.tb05025.x.

38. Tian, J., Ban, X., Zeng, H., Huang, B., He, J., \& Wang, $Y .$, In vitro and in vivo activity of essential oil from dill (Anethum graveolens L.) against fungal spoilage of cherry tomatoes, Food Control, 2011, 22, 12, 1992-1999, https:// doi.org/10.1016/j.foodcont.2011.05.018.

39. An, P., Yang, X., Yu, J., Qi, J., Ren, X., Kong, Q., $\alpha$-terpineol and terpene-4-ol, the critical components of tea tree oil, exert antifungal activities in vitro and in vivo against Aspergillus niger in grapes by inducing morphous damage and metabolic changes of fungus, Food Control, 2018, https://doi. org/10.1016/j.foodcont.2018.11.013.

40. Knobloch, K., Pauli, A., Iberl, B., Weis, N., Weigand, H., Antibacterial activity and antifungal properties of essential oil components, J Essent Oil Res, 1988, 1, 119128, https://doi.org/10.1080/10412905.198 9.9697767.

41. Beylier, M., Bacteriostatic activity of some Australian essential oils, Perfum Flavour, 1979, 4, 23-25.

42. Morris, J.A., Khettry, A., Seitz, E.W., Antimicrobial activity of aroma chemicals and essential oils, J Am Chem Soc, 1979, 56, 595603, https://doi.org/10.1007/BF02660245.

43. Sikkema, J., de Bont, J.A.M., Poolman, B., Mechanisms of membrane toxicity of hydrocarbons, Microbiol Rev, 1995, 59, 201-222, https://doi.org/10.1128/ MMBR.59.2.201-222.1995. 
44. Hammer, K.A., Carson, C.F., Riley, T.V., Nielsen, J.B., A review of the toxicity of Melaleuca alternifolia (tea tree) oil, Food Chem Toxicol, 2006, 44, 616-625, https://doi. $\operatorname{org} / 10.1016 / j . f c t .2005 .09 .001$.
(C) 2020 by the author(s). Published by INCDTPICPI, Bucharest, RO. This is an open access article distributed under the terms and conditions of the Creative Commons Attribution license (http://creativecommons.org/licenses/by/4.0/). 